3 Hatherley LI, Hayes K, Hennessy EM, Jack I. Herpes virus in an obstetric

hospital. Primary herpetic eruptions. Med $\mathcal{F}$ A ust $1980 ; 2: 205-8$.
Fiddian AP, Yeo JM, Clark AE. Treatment of herpes labialis. $\mathcal{F}$ Infect 1983;6 (suppl 1):41-7.

Fiddian AP, Yeo JM, Stubbings $R$, Dean D. Successful treatment of herpes abialis with topical acyclovir. Br Med $\mathcal{F} 1983 ; \mathbf{2 8 6}: 1699-70$

dian AP, Ivanyi L. Topical acyclovir in the management of recurrent herpes abialis. Br J Dermatol 1983;109:321-6.

Yeo JM, Fiddian AP. Acyclovir in the management of herpes labialis. $f$ Antimicrob Chemother 1983 , 2 (suppl B) $95-103$

an Vloten WA, Swart RNJ, Pot R. Topical acyclovir therapy in patients with recurrent orofacial
9 Kinghorn GR, Turner EB, Barton IG, Potter CW, Burke CA, Fiddian AP Efficacy of topical acyclovir cream in first and recurrent episodes of genital herpes. Antiviral Res 1983;3:291-301.

10 Fiddian AP, Kinghorn GR, Goldmeir D, et al. Topical acyclovir in the treatment of genital herpes: a comparison with systemic therapy. $\mathcal{f}$ Antimicrob Chemother

1983;12 (suppl B):67-77.
11 Luby JP, Gnann JW, Alexander WJ, et al. A collaborative study of patientnitiated treatment of recurrent genital herpes with topical acyclovir or placebo. Infect Dis 1984;150:1-6.

2 Collins P, Appleyard G, Oliver NM. Sensitivity of herpes virus isolates from acyclovir clinical trials. Am $\mathcal{f}$ Med 1982;73:380-2.

Accepted 4 April 1985)

\title{
Relation of gene expression (allotypes) of the fourth component of complement to insulin dependent diabetes and its microangiopathic complications
}

\begin{abstract}
About a quarter of insulin dependent diabetics have low concentrations of the fourth component of complement (C4), and a low concentration of $\mathrm{C4}$ is associated with diabetic microangiopathy. The variability of the expression of the C4 gene was compared in insulin dependent diabetics with and without microangiopathy and controls. Of the two genes coding for $\mathrm{C4}$, the $\mathrm{A}$ gene (C4A) was not expressed-that is, C4A null-in $16(13 \%)$ of the 126 insulin dependent diabetics compared with none of the 93 controls $(p<0.001)$, and all these 16 subjects had low concentrations of C4. Lack of expression of the other C4 gene (C4B) was not associated with insulin dependent diabetes, but a rare variant, C4B3, was significantly increased in the diabetics $(21 / 126 ; 17 \%)$ compared with the controls (none) $(p<0.001)$. The prevalence of C4B3 was also increased in the diabetics with complications when compared with those without (14/50 $(28 \%)$ v $7 / 76(9 \%), p<0.01)$.

Low plasma C4 concentrations in insulin dependent diabetics are at least partly due to variation in the expression of the $\mathrm{C4}$ gene. The association of the rare C4B3 variant with microangiopathy suggests a genetic component of its aetiology.
\end{abstract}

\section{Introduction}

Environmental (possibly viral) and genetic factors appear to have a role in the pathogenesis of insulin dependent diabetes. ${ }^{1-3}$

\footnotetext{
Departments of Medicine and Immunology, University of Birmingham, Birmingham

C MIJOVIC, BSC, research associate

J FLETCHER, MA, MRCP, research fellow

A R BRADWELL, FRCP, senior lecturer and honorary consultant immunologist

A H BARNETT, MD, MRCP, senior lecturer and honorary consultant physician, East Birmingham Hospital

Manor Hospital, Walsall

T HARVEY, FRCP, consultant physician

Correspondence to: Dr A H Barnett, East Birmingham Hospital, Birmingham B9 5ST.
}

We previously reported that about a quarter of insulin dependent diabetics have low plasma concentrations of the fourth component of complement (C4). ${ }^{45}$ Low C4 concentrations are found irrespective of age or duration of disease ${ }^{4}$ and are associated with diabetic microangiopathy. ${ }^{5}$ Studies of identical twins ${ }^{4}$ and families ${ }^{5}$ suggest that the characteristic of low concentrations of C4 is inherited. As C4 is important in viral neutralisation ${ }^{6}$ and the clearance of immune complexes ${ }^{7}$ it might have a role in the pathogenesis of insulin dependent diabetes and its microvascular complications.

The genes that code for $\mathrm{C} 4$ are on the short arm of chromosome 6 in the HLA region, this region being concerned with cellular and humoral immune responses. ${ }^{8}$ Two genes, $\mathrm{C} 4 \mathrm{~A}$ and $\mathrm{C} 4 \mathrm{~B}$, each contribute to about half of the total serum C4 concentration. Both are highly polymorphic: 13 different variants (allotypes) have been described for the A protein and 22 for the B protein. In addition, non-expressed (null) genes have been described at each locus, which lead to lower serum concentrations of $\mathrm{C} 4 .^{9}$ The prevalence of null alleles is increased in insulin dependent diabetics, ${ }^{10}$ as are other rare $\mathrm{C} 4$ allotypes. ${ }^{10}{ }^{11}$ We studied the prevalence of $\mathrm{C} 4$ allotypes in normal controls and in insulin dependent diabetics with and without microangiopathy.

\section{Subjects and methods}

We studied 126 white insulin dependent diabetics routinely attending two diabetic clinics in the West Midlands. Insulin dependence was defined on the basis of initial acuteness of presentation, a tendency to ketosis, requirement for insulin from diagnosis, and age at onset. Of the 126 insulin dependent diabetics, 76 had no evidence of microangiopathic complications and 50 had retinopathy with or without persistent proteinuria. Retinopathy was diagnosed by ophthalmoscopic features through dilated pupils and in most cases was confirmed by fluorescein angiography. Twenty nine subjects had severe complications (proliferative retinopathy with or without proteinuria or background retinopathy and proteinuria).

The mean (SD) age of the diabetics with complications was 36 (11) years (range 18-63) and of those without complications 28 (11) years (range 14-57). The respective durations of diabetes were 20 (9) years (range 7-35) and 12 (9) years (range 1-38).

Ninety three healthy non-diabetic white university undergraduates attending the local blood transfusion centre were studied as a control group (most were aged 18-22). None had a family history of diabetes.

Plasma C4 concentration was measured by radial immunodiffusion, and values $\leqslant 0.23 \mathrm{~g} / \mathrm{l}$ were defined as low, as previously described. ${ }^{5}$ Phenotyping of $\mathrm{C} 4$ was performed by agarose gel electrophoresis of neuraminidase treated edetic acid plasma with immunofixation. ${ }^{12}$ 
This technique separates the products of the two $\mathrm{C} 4$ loci into two proteins, C4A and C4B. Each protein is represented by three bands on the agarose gel, and it is the position of the leading band that determines the allotype. The $A$ protein is more acidic than the $B$ protein and migrates further towards the anode, and the designation of the allotype depends on the rate of electrophoretic migration. If the gene is not expressed then there are no bands of protein (quantity zero or Q0). Thus possession of two null $A$ alleles is defined as C4AQ0Q0, and similarly for the null B alleles. Heterozygous null alleles were detected using crossed immunoelectrophoresis. ${ }^{13}$ Statistical analysis was by the $\chi^{2}$ test and Fisher's exact probability test where appropriate.

\section{Results}

There was a highly significant increase in the prevalence of the null $\mathrm{C} 4 \mathrm{~A}(\mathrm{C} 4 \mathrm{AQ} 0 \mathrm{Q} 0)$ phenotype and $\mathrm{C} 4 \mathrm{~B} 3$ allotype and a reduced prevalence of the $\mathrm{C} 4 \mathrm{~A} 3$ allotype in the diabetic group compared with the controls (table I). No significant difference was seen in the prevalence of the homozygous $\mathrm{B}$ null phenotypes (BQ0Q0) between these groups.

There was a highly significant increase in the prevalence of the C4B3 allotype in the diabetics with complications compared with those without (table II). The prevalence of the C4AQ0Q0 phenotype was also increased in those with complications, but this did not reach significance. The patients with severe complications showed no significant increase in the prevalence of the C4B3 allotype $(8 / 29 ; 28 \%)$ when compared with the group with complications as a whole $\left(14 / 50 ; 28^{\circ} \%\right)$. A comparison was also made using only those patients without complications whose diabetes was of over 12 years' duration. The groups were thus matched for duration of diabetes (group with complications $(n=50)$, mean (SD) 20 (9) years $v$ group without complications $(n=40), 19$ (9) years). The prevalence of the C4B3 allotype was $14 / 50(28 \%) v 3 / 40(8 \%)$, respectively $(\mathrm{p}<0.02)$. All subjects with $\mathrm{AQ} Q \mathrm{Q} 0$ phenotypes had low plasma $\mathrm{C} 4$ concentrations; and this accounted for $60 \%$ of the subjects with low $\mathrm{C} 4$ concentrations reported on previously.

TABLE I-Comparison of C4 allotypes and homozygous null phenotypes in insulin dependent diabetics and controls

\begin{tabular}{|c|c|c|c|}
\hline C4 allotype* & $\begin{array}{c}\text { No }\left({ }_{0}^{0}\right) \text { of insulin } \\
\text { dependent diabetics } \\
(n=126)\end{array}$ & $\begin{array}{c}\text { No }(\%) \text { of controls } \\
(\mathbf{n = 9 3 )}\end{array}$ & p Value \\
\hline $\begin{array}{l}\mathrm{AQO}+ \\
\mathrm{A} 3 \\
\mathrm{BQO}+ \\
\mathrm{B} 1 \\
\mathrm{~B} 2 \\
\mathrm{~B} 3\end{array}$ & $\begin{array}{r}16(13) \\
81(64) \\
3(2) \\
110(87) \\
34(27) \\
21(17)\end{array}$ & $\begin{array}{r}74(80) \\
7(7) \\
84(90) \\
15(16)\end{array}$ & $\begin{array}{l}<0.001 \\
<0.02 \\
\text { NS } \\
\text { NS } \\
\text { NS } \\
<0.001\end{array}$ \\
\hline
\end{tabular}

*Prevalence of other less common allotypes found (A6, A5, A4, A2, A1, and B6, B5, B4) did not differ significantly between the groups.

tOnly homozygous null phenotype is shown.

TABLE II-Comparison of C.4 allotypes and homozygous null phenotypes in insulin dependent diabetics with and without microangiopathy

\begin{tabular}{ccrc}
\hline C4 Allotype & $\begin{array}{c}\text { No }\left({ }^{\circ}, \text { with }\right. \\
\text { microangiopathy } \\
(\mathbf{n}=50)\end{array}$ & $\begin{array}{c}\text { No }\left({ }_{0}^{\circ}\right) \text { without } \\
\text { microangiopathy } \\
(\mathbf{n}=76)\end{array}$ & p Value \\
\hline $\mathrm{AQO}^{*}$ & $8(16)$ & $8(11)$ & NS \\
A3 & $30(60)$ & $51(67)$ & NS \\
BQO* & $45(90)$ & $3(4)$ & NS \\
B1 & $15(30)$ & $65(86)$ & NS \\
B2 & $14(28)$ & $7(25)$ & $<0.01$ \\
B3 & & $7(9)$ &
\end{tabular}

*Only homozygous null phenotype is shown

\section{Discussion}

The insulin dependent diabetics studied showed a significantly increased prevalence of the C4AQ0Q0 phenotype and the C4B3 allotype and a reduced prevalence of the C4A3 allotype. A predictable association was also seen between the presence of the C4AQOQ0 phenotype and low plasma $\mathrm{C} 4$ concentration; this agrees with data reported elsewhere. ${ }^{10} \mathrm{We}$ also found a significant increase in the prevalence of the C4B3 allotype in insulin dependent diabetics with complications compared with those without. Possession of the AQ0Q0 phenotype did not account for $40^{\circ}$ o of the low plasma $\mathrm{C} 4$ values reported previously. ${ }^{4}$ Many of these subjects were probably heterozygous null for the A or B protein, or both. Phenotyping of parents and siblings, which has not yet been done would be necessary to confirm this. One other report noted a similar association of allotype C4B3 with complications, although this did not achieve significance because of small numbers. ${ }^{14}$ Much controversy remains, however, about the importance of the HLA region in the aetiology of microangiopathy. ${ }^{15}$ It was not possible in this study to compare accurately long term metabolic control in our two groups of insulin dependent diabetics, although there was no obvious difference.

Two hypotheses, which are under evaluation, arise from our observations. Firstly, phenotypic variation of $\mathrm{C} 4$ in insulin dependent diabetics might be important in the aetiology of both insulin dependent diabetes and complications if it caused absolute or functional deficiency of complement, leading to defective clearance of immune complexes, viral neutralisation, or cell lysis. Supportive experimental data for this suggestion are not yet available. A similar relation, however, has been shown in systemic lupus erythematosus, in which there is a high prevalence of null A phenotypes. ${ }^{16}$ Susceptibility to this disease might be directly due to deficiency of a component of complement, and systemic lupus erythematosus, like insulin dependent diabetes, is mediated by immune mechanisms. ${ }^{16}$ Secondly, the relation of our findings to insulin dependent diabetes may be purely that of association (linkage disequilibrium) with more important neighbouring HLA genes.

We conclude that low plasma $\mathrm{C} 4$ concentrations in insulin dependent diabetics are at least partly accounted for by phenotypic variation. Subjects with microangiopathy have an increased prevalence of the rare C4B3 allotype; as the allotype is an inherited characteristic this indicates that there is a genetically related immune component to the aetiology of these complications.

We thank Miss Linda Wells for advice on phenotyping and allotyping of $\mathrm{C} 4$ and Professor R Hoffenberg for critical appraisal of the manuscript. This project was supported by the British Diabetic Association, the West Midlands Regional Research Fund, and Nordisk UK.

\section{References}

1 Yoon JW, Austin M, Onodera T, Notkins AL. Viral induced diabetes mellitus $N$ Engl f Med 1979;300:1173.

2 Champsaur H, Dussaix E, Samoly KD, Fabre $\mathrm{M}$, Bach $\mathrm{CH}$, Assan R. Diabetes and Coxsackie virus B5 infection. Lancet $1980 ; \mathrm{i} \cdot 251-2$.

Wolf E, Spencer KM, Cudworth AG. The genetic susceptibility to type 1 diabetes: analysis of the HLA DR association. Diabetologia 1983;24:224-30.

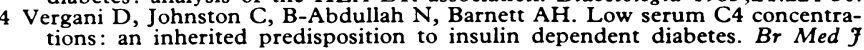
$1983 ; 286: 926-8$. 5 Barnett AH, Mijovic C, Fletcher $\mathrm{J}$, et al. Low plasma C4 concentrations:
association with microangiopathy in insulin dependent diabetes. Br Med $\mathfrak{f}$ $1984 ; 289: 943-5$

6 Leddy JP, Simons RL, Douglas RG. Effect of selective complement deficiency on the rate of neutralisation of enveloped viruses by human sera. $\mathcal{f}$ Immuno 1977; 118:28-34

7 Campbell RD, Dodds AW, Porter RP. The binding of human complemen component C4 to antibody-antigen aggregates. Biochem $f$ 1980;189:67-80. Uko G, Christiansen FT, Dawkins RL, Kay PH. Low serum C4 concentrations

9 in insulin dependent diabetes. $B r$ Med $\mathcal{f} 1983 ; 286: 1748$. ponent of human complement. Proc Natl Acad Sci USA 1980;77:3576-80. 10 McCluskey J, McCann VJ, Kay PH, et al. HLA and complement allotypes in type I (insulin dependent) diabetes. Diabetologia 1983;24:162-5.

11 Bertrams J, Hintzen O, Schlicht V, Schoeps S. C4: another market for type I diabetes. Lancet 1982; i 41

C4 G, Alper CA, Awdeh Z, et al. Statem C4 allotypes. Immunobiol $1983 ; 64: 184-91$.

13 Awdeh ZL Raum D, Alper CA. Genetic polymorphism of human complemen C4 and detection of heterozygotes. Nature P979;282:205. HLA and complement genetic markers in diabetic retinopathy. Diabetologia $1983 ; 24: 221$

15 Barbosa J, Saner B. Do genetic factors play a role in the pathogenesis of diabetic microangiopathy ? Diabetologia 1984;27:487-92.

16 Fielder AHL, Walport MJ, Batchelor JR, et al. Family study of the major histocompatibility complex in patients with systemic lupus erythematosus. 